\title{
Effect of Core Competence on Competitive Advantage and
}

\section{Organizational Performance}

\author{
Sabah Agha (Associate Professor) \\ Department of Business Administration, Faculty of Business \\ Middle East University - MEU, Jordan \\ E-mail: sabah_agha@yahoo.co.uk
}

Laith Alrubaiee (Corresponding author)

Associate Professor, Department of E-Business, Faculty of Business

Middle East University - MEU

PO box 383, Amman 11831, Jordan

Tel: 962-79-699-9576

E-mail: Lalrubaiee@meu.edu.jo/Laith_alrubaiee@Yahoo.com

\author{
Manar Jamhour \\ Engineer, MBA, UAE \\ E-mail: Manar.Jamhour@Fosroc.com
}

Received: May 19, 2011

doi:10.5539/ijbm.v7n1p192
Accepted: September 5, $2011 \quad$ Published: January 1, 2012

URL: http://dx.doi.org/10.5539/ijbm.v7n1p192

\begin{abstract}
In highly competitiveness market core competence has emerged as a central concept for competitive strategy. Core competence is the knowledge set that distinguishes a firm and provides a competitive advantage over others. The main purpose of this study is to investigate the relationship between core competence, competitive advantage and organizational performance. Core competence was measured through three dimensions: shared vision, cooperation and empowerment. Competitive advantage was also measured through flexibility and responsiveness. The proposed model was tested in the context of Paint Industry in the UAE. The survey was administered electronically to a total of 77 managers. Results indicate that it appears to be consistent and reliable scales. Finding indicates that, while core competence has a strong and positive impact on competitive advantage and organizational performance, competitive advantage has also significant impact on organizational performance. Results confirm the varying importance of core competence dimensions on competitive advantage and organizational performance. It has also been found that flexibility have higher impact on organizational performance than responsiveness. To remain competitive and obtain competitive advantages, managers can try to increase organizational performance by managing each dimension of core competence i.e. shared vision; cooperation and empowerment.
\end{abstract}

Keywords: Core competence, Competitive advantage, Organizational performance, UAE

\section{Introduction}

In today highly competitiveness environment, business organizations need to act fast in order to secure their financial situations and their market positions. Firms are continuously striving for ways to attain a sustainable competitive advantage. They need to count more on their internal distinguished strengths to provide more added customer value, strong differentiation and extendibility; in other words count more on their "core competences"( Hamel \& Prahalad, 1994). Therefore, strategy has to move from competing for product or service leadership to competing in core competence leadership. The core competence has to be a primary factor for strategy formulation as it is an important source of profitability. Scholars have acknowledged the importance of 
the core competence concept by suggesting core competence models to sustain competitive advantage (Petts, 1997; Hafeez et al., 2002). One stream of research suggests core competencies to be at the base of all competitive advantage (Srivastava, 2005). A core competency is about the knowledge on successes or failures in recommending knowledge resources (Banerjee, 2003); even some researchers define Core competence in short straight-forward words: "it is the ability to operate efficiently within the business environment and to respond to challenges" (Chen, et al., 2007: 159) linking its definition directly with performance. Companies are likely to be different in terms of their abilities to select, build, deploy, and protect this core Competencies. These differences are likely to yield differences in corporate performance (Hamel, 1994). The concept of core competence has been developed to support more efficient identification and utilization of an organization's strength. The assumption is that core competencies change more slowly over time than products and markets, and are cumulative (Gupta et al., 2009).

The concept of core competence has implications at the strategic level; the firms should systematically work upon identifying their core competencies and developing them for sustainable competitive advantage (Srivastava, 2005). It has also been suggested that the theory of competence-based competition argues that core competencies are the source of sustainable competitive advantage. Core competencies are valuable capabilities those are collective and unique in their characteristics, as well as strategically flexible contributing toward the success of potential business (Hafeez et al., 2002). Moreover, Chen et al. (2007) point out, that the importance of Core competence in the Traditional manufacturing (T-M) sector is higher than in the High-Tech sector. Therefore, this research is of great value for the paint industry since the paint manufacturing is considered as traditional manufacturing. However, since core competencies are key ingredients in organizational success, therefore, the primary purpose of this study is to examine the relationship between core competence, competitive advantage and organizational performance in paint industry. The study was conducted in paint industry firms in emirate which is especially well suited for studying core competence matters due to their diverse product. The study focuses on particular core competencies: shard vision, cooperation, and empowerment as well as two important competitive advantage dimensions: flexibility and responsiveness.

\subsection{Objective of the study}

Addressing the major issues discussed above, we seek to accomplish the following specific objectives:

1) To examine the effects of core competence on competitive advantage variables in the Paint Companies in the UAE.

2) To test the effect of competitive advantage on the organizational performance of the Paint Industry in the UAE.

3) To investigate the effect of core competence on the organizational Performance of the Paint Industry in the UAE.

\subsection{Significance of the study}

Emirate was chosen to investigate the study variables relationship in paint industry since it offer a unique setting to test the relationship from economic standpoint. The Construction Business is with no doubt the highest investment sector in the UAE during the past 5 years and paint industry is an important supplier for this business. Given the fact that UAE experienced a significant construction booming, many multinational and local companies from different sizes entered that promising and rewarding market, including the paint manufacturing companies. And that; of course, added more constraint regarding how any company can compete and acquire good profitable share from such marketplace. Furthermore, the raw materials suppliers for Paint manufacturers are also giant-multinational-multibillion turnover companies, and that adds the third important fact and constraint over those companies, who are located between giant and highly professional business market and consumer, facing all the implications from such position. The significance of this study is further highlighted when one considers the increasing managerial focus on maximizing customers' value in highly competitive market. According to Hamel and Prahalad $(1994 ; 1990)$, a core competence must make a significant contribution to Customer perceived value. Core competences are the skills that empower a firm to provide a fundamental value and customer benefit which leads to customer loyalty. Customer loyalty and customer retention are the most important challenges faced by most of the CEO across the world .Therefore, cultivating loyal customers can lead to increased sales and customer share, lower costs, and higher prices (Alrubaiee \& Alnazer, 2010). Moreover, this study certainly strengthens the existing body of knowledge by providing some empirically tested insight in the UAE- paint industry context. The study's results can provide better information for the decision maker about the Core Competence benefits. 


\section{Theoretical review}

\subsection{Conceptualization of Core competencies}

Leonard-Barton (2000) defined core competency as one which differentiates a firm from its milieu. According to Sanchez and Heene (1997), core competencies are usually the result of "collective learning" processes and are manifested in business activities and processes. The core competencies are those unique capabilities, which usually span over multiple products or markets (Hafeez et al., 2002). Javidan (1998) points out, that core competency is a collection of competencies that are widespread in the corporation. It results from the interaction between different SBUs' competencies. Core competencies are skills and areas of knowledge that are shared across business units and result from the integration and harmonization of SBU competencies. One useful finding of Hafeez et al.,(2002) analysis is that although Company A regards its core business as manufacturing engineering, the core competencies reside in the sales and marketing area. Prahalad and Hamel (1990) contend that "core competencies are the collective learning in the organizations, especially how to coordinate diverse production skills and integrate multiple streams of technologies." They argue that core competence is communication, involvement, and a deep commitment to working across organizational boundaries (Gupta et al., 2009). Ljungquist (2008) point out, that Core competence was originally invented as a tool for justifying business diversification at large companies, and for supporting internal processes such as product development (Prahalad and Hamel, 1990). Scholars have acknowledged the importance of the concept by advancing it in multiple directions: by connecting it to conceptual notions of learning (Lei et al., 1996), by suggesting core competence models to sustain competitive advantage (Petts, 1997; Hafeez et al., 2002), by building on the concept's basic notions to invent similar concepts (Sanchez \& Heene, 1997; Eden \& Ackermann, 2000; Sanchez, 2004), and by developing processes for its identification ( Javidan, 1998; Eden \& Ackermann, 2000). The importance of the concept is also acknowledged when testing the implementation of core competence as strategy (Clark, 2000; Clark \& Scott, 2000). It is argued that in addition to identifying competences, the critical task is to assess them relative to those of competitors. Although a firm may identify a host of competences that it performs better relative to its competitors, not all competences are "core". Core competences are those competences which allow firms a superior advantage, and according to Hamel and Prahalad $(1994 ; 1990)$ to be considered "core" the competence must meet three criteria:

(1) Customer Value: A core competence must make a significant contribution to Customer perceived value.

(2) Competitor Differentiation: Any competence across an industry cannot be defined as core unless the firm's level of competence is superior to all its competitors and should be difficult for to imitate.

(3) Extendibility: The competence must be capable of being applied to new product arenas.

Most of authors have focused on three dimensions of core competence, they are: Shared vision, Cooperation and Empowerment (Sanchez, 2004; Hafeez et al., 2002; Javidan, 1998; King \& Zeithaml, 2001; Hafeez \& Essmail, 2007). Therefore, the study focuses on these three key dimensions of core competence. Shared vision is defined as a firm's interest in sharing the organization's view of goals, objectives, policies, priorities, and expectations (Santos-Vijande et al., 2005). It is essential to guarantee learning to occur in the same direction and to motivate that it really takes places. Firms with greater shared vision likely enhance to business excellence and success. Then, firms seem to utilize the shared vision to build innovative products and services and fulfill customer and market requirements (Ussahawanitchakit, 2008). Cooperation is also a key factor that plays a role in the development of core competence. Cooperation is a joint behavior toward a particular goal of common interest that involves interpersonal relationships (Croteau et al., 2001). Cooperation as a Core competence knows when and how to attract, reword, and utilize teams to optimize results. Acts to build trust, inspire enthusiasm, encourage others, and help resolve conflicts and develop consensus in creating high performance (Berger et al., 2004). Empowerment is a process or psychological state manifested in four cognitions: meaning, competence, self- determination, and impact. Specifically, meaning concerns a sense of feeling that one's work is personally important (Zhang \& Partol, 2010). Empowering tends to enhance the meaningfulness of work by helping an employee understand the importance of his or her contribution to overall organizational effectiveness.

\subsection{Competitive Advantage}

If a firm possesses resources and capabilities which are superior to those of competitors, then as long as the firm adopts a strategy that utilizes these resources and capabilities effectively, it should be possible for it to establish a Competitive advantage. The sustainability of competitive advantage depends on three major characteristics of resources and capabilities: Durability; which is the period over which a competitive advantage is sustained, Transferability; the harder a resource is to transfer the higher sustainable the competitive advantage, and finally Replicability; means cannot be replicated or purchased from a market (Sadler, 2003). 
A competitive advantage is meaningful if it is related to an attribute valued by the market. Customers need to perceive a consistent difference in important attributes between the producer's products or services and those of its competitors. These differences must relate to some product/delivery attributes which are among the key buying criteria for the market.' Product/delivery attributes are those variables that impact the customers' perceptions of the product or service, its usefulness and its availability. Some examples of such attributes are product quality, price and after-sale service. Key buying criteria are those variables and criteria that customers use in making their purchase decisions. They are different for different industries and different market segments (Javidan, 1998). Gupta et al. (2009) point out, that resources alone are frequently not enough to generate competitiveness over other firms. In creating a competitive advantage, a firm needs the ability to make good use of resources - defined as the capability to handle a given matter - and, as the ability grows over time, to utilize the available resources to create new resources, such as skills (through new technology or software application), or to open new doors to the development of new types of product. "A firm is said to have a competitive advantage when it is implementing a value creating strategy not simultaneously being implemented by any current or potential player" (Clulow et al., 2003). To gain competitive advantage a business strategy of a firm manipulates the various resources over which it has direct control and these resources have the ability to generate competitive advantage (Rijamampianina, 2003). Superior performance outcomes and superiority in production resources reflects competitive advantage (Lau, 2002). Most of authors have focused on two dimensions of Competitive advantage: Flexibility and Responsiveness (Evans, 1993; Krajewski \& Ritzman, 1996; Macmillan \& Tampo, 2000). Therefore, our study focuses on these two key dimensions of competitive advantage. Flexibility defined as the firm's intent and capabilities to generate firm-specific real options for the configuration and reconfiguration of appreciably superior customer value propositions (Johnson et al., 2003). Responsiveness refers to the firm's ability to respond quickly to customer needs and wants (Carlos et al., 2010)

\subsection{Organizational Performance}

Performance is a continuous and flexible process that involves managers and those whom they manage acting as partners within a framework that sets out how they can best work together to achieve the required results (Armstrong, 2006). Performance is the end result of activities; it includes the actual outcomes of the strategic management process. The practice of strategic management is justified in terms of its ability to improve the organization's performance (Wheelen \& Hunger, 2010). Although organizational performance encompasses many specific areas of firm outcomes i.e. dimensions ( Richard et al., 2009; Thang et al., 2008; Morgan \& Strong, 2003; Nwokah, 2008), we focused only on two key dimensions to measure organizational performance: Growth and Profitability.

\subsection{Core Competence, Competitive Advantage and Organizational performance}

Studies on the core competencies offer a wide array of explanations about the concept of core competencies and their role in enhancing the competitive advantage of the firm (Srivastava, 2005). Bogner et al. (1999) expect that academics, business executives and consultants will be able to further develop normative and theoretical propositions that will enrich the understanding of competence and dynamic competitive advantage. Therefore, competitive advantage and core competency are not necessarily the same, but can be (and should be) closely related because a successful competitive strategy is built on the firm's core competencies and competitive advantages (Javidan, 1998). Core competence is the knowledge set that distinguishes a firm and provides a competitive advantage over others (Leonard-Barton, 1992). Core competencies when viewed as unique knowledge for problem definition and problem solving can form the basis of a firm's competitive advantage and can also be leveraged in a wide variety of markets for future products (Srivastava, 2005). Calantone et al. (2002) found that shared vision has a positive effect on an organization's innovativeness, which in turn affects organizational performance. Bani-Hani \& AL-Hawary (2009) indicated that there is a significant positive relationship between core competences and competitive advantage. The study also showed that the core competences had a significant impact on competitive advantage.

\section{Conceptual framework and hypotheses development}

\subsection{Conceptual framework}

The proposed conceptual model guiding this research is depicted in Figure 1. As can be seen in the figure, we hypothesize core competence as a multi-dimensional construct consisting of three dimensions: shared vision; cooperation and empowerment. These three dimensions were modeled with competitive advantage and organizational performance as the dependents.

Insert Figure 1 here 
We suggest core competence to be significant determinant of competitive advantage and organizational performance i.e. more core competence lead to higher levels of competitive advantage and organizational performance. Then, we propose that competitive advantage as a multi-dimensional construct consisting of two dimensions: Flexibility and Responsiveness. These dimensions act as antecedents to organizational performance. For the paint firm to maintain competitive advantage and enhances organizational performance should improve their core competencies.

\subsection{Research Hypotheses}

Therefore, to examine these relationships we developed three research hypotheses:

H1: Core Competence (Shared Vision; Cooperation and Empowerment) has positive effect on Organizational Performance.

H2: Core Competence (Shared Vision; Cooperation and Empowerment) has positive effect on Competitive Advantage

H3: Competitive advantage (Flexibility; Responsiveness) has positive effect on Organizational Performance.

\section{Research Methodology}

This study is descriptive quantitative in nature, aiming to develop a better understanding of the core Competence and its relation to Competitive Advantage and organizational performance from the managers point of view .

\subsection{Selection of sample and respondents demographics.}

The study is empirical based on the primary data collected from paint company managers in UAE in 2010. Total of (11) companies were included in the study. In total (77) questionnaires were distributed to the managers. The number of usable returned questionnaires was (64) giving response rate $82 \%$, a rate that is regarded as good. The survey was administered electronically. The Questionnaire was in English, which is the communication language in the UAE (Jamhour, 2010). A majority of the respondents (94\%) were male. As to the educational qualification, $48 \%$ had obtained a university degree, and (52\%) held a postgraduate degree. $50 \%$ of the participants were aged between $(30-40)$ years and the majority of the participants $(52 \%)$ with job experience between $(5-10)$ years .

\subsection{Data analysis}

The statistical package SPSS (version 17.0) was used for data analysis. Two steps of detailed statistical analysis of data were involved. At the first stage, descriptive statistic analysis was performed to extract the mean and standard deviation of underlying study variables core competence, competitive advantage, organizational performance and their dimensions. At the second stage, multiple regression analysis was performed to understand the relationship among these variables.

\subsection{Scale and Measurement}

This study required developing a multidimensional core competence measurement scale and a competitive advantage scale as well as organizational performance scale. As discussed in the above section, we have identified core competence to be multidimensional construct consisting of three dimensions: Shared Vision; Cooperation and Empowerment). This scale was developed by adapting scale developed by King and Zeithaml (2001). The scales measured in a five-point Likert-scale format from "strongly disagree" (1) to "strongly agree" (5). The descriptive statistics of these dimensions presented in tables 1, 2 and 3.

\section{Insert Table 1 here \\ Insert Table 2 here \\ Insert Table 3 here}

As can be seen in tables 1, 2 and 3, with mean scores (4.01), (3.72) and (3.84) on $1-5$ likert scale result indicate high level of the three dimensions of core competence: shared vision, Cooperation and Empowerment in paint industry in UAE. For competitive advantage we use scale developed by Certo and Peter (1995) and Macmillan and Tampo (2000) through two dimensions: Flexibility and responsiveness. The scales also measured in a five-point Likert-scale format from "strongly disagree" (1) to "strongly agree" (5). The descriptive statistics of these dimensions are depicted in tables (4) and (5).

\section{Insert Table 4 here \\ Insert Table 5 here}


As presented in table 4 and 5, with mean scores (3.78) and(3.80) on $1-5$ likert scale result indicate high level of the two dimensions of competitive advantage: Flexibility and Responsiveness in paint industry in UAE. Organizational Performance scale was developed by adapting scale suggested by Moore and Fairhurst (2003) through two dimensions: growth and profitability. Similarly, the scales also measured in a five-point Likert-scale format from "much less than competitors" (1) to "much more than competitors" (5). The descriptive statistics of these dimensions are depicted in tables 6 and 7.

\section{Insert Table 6 here \\ Insert Table 7 here}

As can be seen in tables 6 and 7, with mean scores (3.95) and (3.89) on $1-5$ likert scale result indicate high level of the two dimensions of Organizational Performance: Growth and Profitability in paint industry in UAE.

\subsection{Measure reliability}

Scale Items were pre tested for relevance, face validity, interpretation and readability with academics. Therefore some modifications and slight changes in wording were required to fit the paint industry context. As the first step in analysis of the scale, internal reliability for the adapted scale was compared to that reported in the developmental literature. Scales as presented in table 8 showed a good internal consistency.

\section{Insert Table 8 here}

As can be seen in table 8 Cronbach alpha reliability coefficients are at acceptable levels and fall between 0.83 .8 for the flexibility scale and 0.93 .8 for empowerment .The overall questionnaire presented a Cronbach alpha of 0.97 . Nunnally (1978) indicated 0.7 to be an acceptable reliability coefficient.

\section{Results}

\subsection{Test of Hypotheses}

Using multiple regressions, significant associations were found between Core Competence, Competitive Advantage and Organizational performance.

\subsubsection{Hypothesis 1}

H1 postulates that Core Competence (Shared Vision; Cooperation and Empowerment) has positive effect on Organizational Performance.

In order to test this hypothesis, we conducted a multiple regression analysis using Organizational Performance as the dependent variable, and the various components of Core Competence: Shared Vision; Cooperation and Empowerment as the predicting variables. Table 9 present the regression results of the variables.

\section{Insert Table 9 here}

Table 9 shows that Core Competence (Shared Vision; Cooperation and Empowerment) has a significant positive effect on Organizational Performance. The regression model achieve a high degree of fit, as reflected by an R2 of $0.741(\mathrm{~F}=33.820 \mathrm{p}<0.001)$. The results in Table 9 show that all dimensions of core competence were significant in explaining Organizational Performance. These finding supports H1, which predicted that Core Competence dimensions: shared vision; cooperation and empowerment have a positive effect on organizational performance.

\subsubsection{Hypothesis 2}

$\mathrm{H} 2$ postulates that core competence (shared vision; cooperation and empowerment) has positive effect on competitive advantage.

In order to test this hypothesis, we conducted a multiple regression analysis using competitive advantage as the dependent variable, and the various components of Core Competence: Shared Vision; Cooperation and Empowerment as the predicting variables. Table 10 present the regression results of the variables.

\section{Insert Table 10 here}

Table 10 shows that Core Competence (Shared Vision; Cooperation and Empowerment) has a significant positive effect on competitive advantage. The regression model achieve a high degree of fit, as reflected by an $\mathrm{R} 2$ of $0.360(\mathrm{~F}=11.257 \mathrm{p}<0.001)$. The results in Table 10 show that all dimensions of Core Competence were significant in explaining competitive advantage. These finding supports $\mathrm{H} 2$, which predicted that Core Competence (Shared Vision; Cooperation and Empowerment) has a positive effect on competitive advantage. 


\subsubsection{Hypothesis 3}

H3 postulates that competitive advantage (flexibility; responsiveness) has positive effect on organizational performance.

To test this hypothesis, we conducted a multiple regression analysis using organizational performance as the dependent variable, and the two dimensions of competitive advantage: flexibility and responsiveness as the predicting variables. Table 11 present the regression results of the variables.

\section{Insert Table 11 here}

Table 11 shows that competitive advantage (flexibility; responsiveness) has a significant positive effect on organizational performance. The regression model achieve a high degree of fit, as reflected by an R2 of 0.305 (F $=13.361 \mathrm{p}<0.001)$. The results in Table 11 show that the two dimensions of competitive advantage: flexibility; responsiveness were significant in explaining organizational performance. These finding supports $\mathrm{H} 3$, which predicted that competitive advantage: flexibility; responsiveness has positive effect on organizational performance.

\section{Conclusions and implications}

This study provides initial empirical evidence of the relationship between core competence, competitive advantage and organizational performance. We consider core competence to be a vital determinant of competitive advantage and organizational performance. Study indicated that all three dimensions of core competence i.e. shared vision; Cooperation and empowerment were significant in explaining organizational performance. These results are consistent with Calantone et al. (2002) finding. Moreover, the three dimensions of core competence were also significant in explaining competitive advantage. These results are also consistent with Srivastava (2005); Bogner et al. (1999); Javidan (1998) and Bani-Hani \& AL-Hawary (2009) finding, which argued that core competencies are key component in enhancing the competitive advantage. Therefore, core competence can improve competitive advantage and organizational performance. The results of the regression analyses provide support for the three hypothesized relationships. Consistent with $\mathrm{H} 1$, that Core Competence dimensions shared vision, cooperation and empowerment has a significant positive effect on Organizational Performance. In accordance with H 2, there is significant effect of core competence (shared vision; cooperation and empowerment) on competitive advantage. For $\mathrm{H} 3$ that competitive advantage (flexibility and responsiveness) has positive effect on organizational performance. The study provides empirical evidence of the effects of core competence on competitive advantage and organizational performance. Therefore, paint industry managers can use the current findings to develop strategies that deepen competitive advantage and enhance organizational performance. The current findings may be used by managers to differentiate themselves in a competitive paint industry marketplace. To remain competitive and obtain competitive advantages, managers of paint firms can try to increase organizational performance by managing each dimension of core competence i.e. shared vision; cooperation and empowerment in the context of paint industry.

\section{References}

Acquaah, M. (2007). Managerial social capital, strategic orientation, and organizational performance in an emerging economy. Strategic Management Journal, 28, 12, 1235-1255. http://dx.doi.org/10.1002/smj.632

Ahearne, M., Mathieu, J., \& Rapp, A. (2005). To empower or not to empower your sales force? An empirical examination of the influence of leadership empowerment behavior on customer satisfaction and performance. Journal of Applied Psychology, 90, 945-955. http://dx.doi.org/10.1037/0021-9010.90.5.945

Allen, R., and Helms, M. (2002). Employee perceptions of the relationship between strategy, rewards, and organizational performance. Journal of Business Strategies, 19, 2, 115-39.

Alrubaiee, L., \& Alnazer, N. (2010). Investigate the Impact of Relationship Marketing Orientation on Customer Loyalty: The Customer's Perspective. International Journal of Marketing Studies, 2, 1, May, 155-174.

Armstrong, M. (2006). Performance management: Key strategies and practical guidelines. (3rd ed.). Kogan Page.

Baker, W.E., and Sinkula, J.M. (1999). The synergistic effect of market orientation and learning orientation on organizational performance. Academy of Marketing Science Journal, 27, 4, 411-27. http://dx.doi.org/10.1177/0092070399274002

Banerjee, P. (2003). Resource dependence and core competence: insights from Indian software firms. Technovation, 23: 251-263. http://dx.doi.org/10.1016/S0166-4972(01)00120-1 
Bani-Hani, J. S., and AL-Hawary, F. (2009). The Impact of Core Competences on Competitive Advantage: Strategic Challenge. International Bulletin of Business Administration, 6, 93-104.

Barney, J.B. (1986). Types of Competition and the Theory of Strategy: Toward an Integrative Framework. Academy of Management Review, 11, 791-800.

Berger L. A., and Berger D. R. (2004). The Talent Management Handbook. McGraw-Hill.

Bogner, W. H., Thomas, H., and McGee, j. (1999). Competence and Competitive Advantage: Towards a Dynamic Model. British Journal of Management, 10, 275-290. http://dx.doi.org/10.1111/1467-8551.00139

Calantone, R.J., Cavusgil, S.T., and Zhao, Y. (2002). Learning orientation, firm innovation capability, and firm performance. Industrial Marketing Management, Vol. 31, No. 6: 515-24. http://dx.doi.org/10.1016/S0019-8501(01)00203-6

Calcagno, Monica. (2004). The Evolution of the Competitive Advantage Concept in Strategic Management Studies. Working Paper, 2.

Carayannis, E. G., \& Alexander, J. (2002). Is technological learning a firm core competence, when, how and why? A longitudinal, multi-industry study of firm technological learning and market performance. Technovation, 22, 625-643. http://dx.doi.org/10.1016/S0166-4972(01)00047-5

Carlos, M.P., Sousa, E.R., and Fernando, L. (2010). The Key Role of Managers' Values in Exporting: Influence on Customer Responsiveness and Export Performance. Journal of International Marketing, 18, 2, 2010, 1-19.

Certo, S.C., Paul, P.J., and Otten, S. E. (1995). The Strategic Management Process. (3 ${ }^{\text {rd }}$ Ed.). Prentice-USA, Austen Press, Irwin Inc.

Chacarbaghi and Lynch. (1999). Competitive Advantage: Creating and Sustaining Superior Performance by Michael E. Porter 1980. cited by Chacarbaghi and Lynch 1999, p. 45.

Chen, Yu-fen and $\mathrm{Wu}$, Tsui-chih. (2007). An empirical analysis of core competence for high-tech firms and traditional manufacturers. Journal of Management Development, 26, 2, 159-168.

Clulow, V., Gerstman, J., and Barry, C. (2003). The resource-based view and sustainable competitive advantage: the case of a financial services firm. Journal of European Industrial Training, Vol. 27, No.5: 220-232. http://dx.doi.org/10.1108/03090590310469605

Coulter, Mary. (2003). Strategic Management in Action. ( $2^{\text {nd }}$ ed.). Prentice Hall, Upper Saddle River, New Jersey.

Croteau Ann-M, Solomon S., Raymond L., and Bergeron F. (2001). "Organizational and Technological Infrastructures Alignment", hicss, vol. 8, pp.8049, 34th Annual Hawaii International Conference on System Sciences ( HICSS-34)-Volume 8, 2001

Escrig-Tena, Ana Belen and Bou-Llusar, Juan Carlos. (2005). A Model for Evaluating Organizational Competences: An Application in the Context of a Quality Management Initiative. Decision Sciences, Vol.36, No.2. http://dx.doi.org/10.1111/j.1540-5414.2005.00072.x

Evans, James R. (1993). Applied Production and Operations Management. (4th ed.). West Pub Co.

Goddard, J. (1997). The architecture of core competence. Business Strategy Review, Vol. 8, No. 1: 43-52. http://dx.doi.org/10.1111/1467-8616.00006

Gupta, S., Woodside, A., Dubelaar, C., and Bradmore, D. (2009). Diffusing knowledge-based core competencies for leveraging innovation strategies: Modeling outsourcing to knowledge process organizations (KPOs) in pharmaceutical networks. Industrial Marketing Management, 38, 219-227. http://dx.doi.org/10.1016/j.indmarman.2008.12.010

Hafeez, Khalid \& Essmail, Essmail Ali. (2007). Evaluating organization core competences and associated personal competences using analytical hierarchy process. Management Research News, Vol. 30 No. 8: 530-547. http://dx.doi.org/10.1108/01409170710773689

Hafeez, Khalid; Zhang, Y., and Malak, N. (2002). Core competence for sustainable competitive advantage: a structured methodology for identifying core competence. IEEE Transactions on Engineering Management, Vol. 49 No. 1: 28-35. http://dx.doi.org/10.1109/17.985745

Hagan, C. M. (1996). The core competence organization: Implications for human resource practices. Human Resource Management Review, Vol. 6, No. 2: 147-164. http://dx.doi.org/10.1016/S1053-4822(96)90017-0 
HagstrÖm, Tom; Tomas, BackstrÖm and Susanna, GÖransson. (2009). Sustainable competence: a study of a bank. The Learning Organization, Vol. 16 No. 3: 237-250. http://dx.doi.org/10.1108/09696470910949953

Hamel, G and Prahalad, C.K. (1990). The core competence of the corporation. Harvard Business Review, Vol. 68 No. 3: 79-92.

Hamel, G., and Prahalad, C. (1994). The concept of core competence, in Hamel, G. and Heene, A. (Eds), Competence-Based Competition, Wiley, New York, NY: 11-33.

Higgins, J. M. (1996). Achieving the Core Competence: It's as Easy as 1,2,3...47,48,49. Business Horizons, Vol. 39, No. 2: 27-32. http://dx.doi.org/10.1016/S0007-6813(96)90020-8

Jamhour, Manar. (2010). The Impact of Core Competence on Organizational Performance. unpublished thesis, Middle East University, Amman.

Javidan, Mansour. (1998). Core Competence: What Does it Mean in Practice?. Long Range Planning, Vol. 31 No. 1: 60-70. http://dx.doi.org/10.1016/S0024-6301(97)00091-5

Johnson G, Scholes K, \& Whittington R. (2008). Exploring corporate strategy; Text and Cases. FT Prentice Hall, Pearson Education. $8^{\text {th }}$ Edition

Johnson J. L, Lee R. P., Saini A., and Grohmann. B. (2003). Focused Strategic Flexibility: Conceptual Advances and an Integrative Model. Journal of the Academy of Marketing, Vol.31, No.1: 74-89. http://dx.doi.org/10.1177/0092070302238603

King, Adelaide Wilcox \& Zeithaml, Carl, P. (2001). Competences and Firm Performance: Examining the Causal Ambiguity Paradox. Strategic Management Journal, Vol.22: 75-99. http://dx.doi.org/10.1002/1097-0266(200101)22:1<75::AID-SMJ145>3.0.CO;2-I

Krajewski, L.I., \& Ritzman, L.P. (1996). Operations Management: Strategy and Analysis. (4th ed.). Addison-Wesley Co., Inc., U.S.A.

Lau, Ronald S. (2002). Competitive Factors and Their Relative Importance in the U.S. Electronics and Computer Industries. International Journal of Operations and Production Management, 22(1), pp. 125-135. http://dx.doi.org/10.1108/01443570210412105

Lei, D., Hitt, M., \& R. Bettis. (1996). Dynamic Core Competences through Meta-Learning and Strategic Context. Journal of Management, 22(4), 549-569. http://dx.doi.org/10.1177/014920639602200402

Leonard-Barton, D. (1992). Core capabilities and core rigidities: A paradox in managing new product development. Strategic Management Journal, 13(Special issue), 111-125. http://dx.doi.org/10.1002/smj.4250131009

Ljungquist, Urban. (2008). Specification of core competence and associated components: A proposed model and a case illustration. European Business Review, Vol. 20, No. 1:73 - 90 . http://dx.doi.org/10.1108/09555340810843708

Macmillan, Hugh \& Tampoe, Mahen. (2000). Strategic Management. Oxford University Press.

Moore, Marguerite \& Fairhurst, Ann. (2003). Marketing Capabilities and Firm Performance in fashion retailing. Journal of Fashion Marketing and Management, Vol.7, No.4: 386-397. http://dx.doi.org/10.1108/13612020310496976

Morgan, R.E., and Strong, C.A. (2003). Business performance and dimensions of strategic orientation. Journal of Business Research, Vol.56, No. 3: 163-176. http://dx.doi.org/10.1016/S0148-2963(01)00218-1

Murray, Peter \& Donegan, Kevin. (2003). Empirical linkages between firm competences and organizational learning. Learning Organization, Vol. 10, No. 1: 51 - 62. http://dx.doi.org/10.1108/09696470310457496

Nunnally, J.C. (1978). Psychometric theory (2nd ed.). New York: McGraw Hill.

Nwokah, N.G. (2008). Strategic market orientation and business performance: the study of food and beverages organizations in Nigeria. European Journal of Marketing, Vol. 42, No.4: 279-286. http://dx.doi.org/10.1108/03090560810852922

O'Sullivan, Don \& Abela, Andrew V. (2007). Marketing Performance Measurement Ability and Firm Performance. Journal of Marketing, Vol. 71: 79-93. http://dx.doi.org/10.1509/jmkg.71.2.79

Passemard \& Calantone. (2000). Competitive Advantage: Creating and Sustaining Superior Performance by Michael E. Porter 1980, cited by Passemard \& Calantone 2000:18 
Pearce, C. L., Sims, H. P., Cox, J. F., Ball, G., Schnell, E., Smith, K. A., \& Trevino, L. (2003). Transactors, transformers and beyond: A multi-method development of a theoretical typology of leadership. Journal of Management Development, 22(4): 273-307. http://dx.doi.org/10.1108/02621710310467587

Porter, M.E. (1985). Competitive Advantage. New York: Free Press.

Porter, M.E. (1991). Towards a Dynamic Theory of Strategy. Strategic Management Journal, Vol.12, Winter: pp.95-117. http://dx.doi.org/10.1002/smj.4250121008

Richard, P.J., Devinney, T.M., Yip, G.S., \& Johnson, G. (2009). Measuring organizational performance: Towards methodological best practice. Journal of Management, vol. 35, no. 3, pp. 718-804. http://dx.doi.org/10.1177/0149206308330560

Rijamampianina, Rasoava, Abratt, Russell, February, Yumiko. (2003). A framework for concentric diversification through sustainable competitive advantage. Management Decision, Vol. 41 Issue 4, p362.

Sadler P. (2003). Strategic Management, ( $2^{\text {nd }}$ Edition.). Kogan Page Limited.

Sanchez and Heene, A. (1997). Reinventing strategic management: New theory and practice for competence-based competition. Eur. Manage. J., vol. 15, no. 3, pp. 303-317. http://dx.doi.org/10.1016/S0263-2373(97)00010-8

Sanchez, Ron. (2004). Understanding competence-based management Identifying and managing five modes of competence. Journal of Business Research, Vol. 57: 518- 532. http://dx.doi.org/10.1016/S0148-2963(02)00318-1

Santos-Vijande, Maria Leticia, Sanzo-Perez, Maria Jose, Alvarez-Gonzalez, Luis I., and Vazquez- Casielles, Rodolfo. (2005). Organizational Learning and Market Orientation: Interface and Effects on Performance. Industrial Marketing Management, Vol.34: 187-202. http://dx.doi.org/10.1016/j.indmarman.2004.08.004

Sekaran, Uma. (2003). Research Methods for Business. John Wiley \& Sons.

Shalley, C. E., \& Gilson, L. L. (2004). What leaders need to know: A review of social and contextual factors that can foster or hinder creativity. Leadership Quarterly, 15: 33-53. http://dx.doi.org/10.1016/j.leaqua.2003.12.004

Sinkula, Baker, William E., and Noordewier, Thomas. (1997). A Framework of Market-Based Organizational Learning: Linking Values, Knowledge, and Behavior. Journal of the Academy of Marketing Science, 25(4): 305-318. http://dx.doi.org/10.1177/0092070397254003

Slack, Nigel, Chambers, S., Harland, C., Harrison, A., \& Johanston, R. (1998). Operations Management (2nd ed.). Pitman Pub, London.

Srivastava, Shirish. (2005). Managing Core Competence of the Organization. Vikalpa, Volume 30, No 4, October - December, 49-68.

Subramanian, Ram, Kamalesh Kumar and Karen Strandholm. (2009). The role of organizational competences in the market-orientation-performance relationship: An empirical analysis. International Journal of Commerce and Management, Vol. 19 No. 1: 7-26. http://dx.doi.org/10.1108/10569210910939645

Thang N.N., Buyens D., and Leuven V. (2008). Training, Organizational Strategy and Firm Performance. The Business Review, Cambridge, Vol. 11, Num. 2.

Thatte A. A. (2007). Competitive Advantage of a Firm through Supply Chain Responsiveness and SCM Practices. The University of Toledo.

Ussahawanitchakit P. (2008). Impacts of organizational learning on innovation orientation and firm efficiency: an empirical assessment of accounting firms in Thailand. International Journal of Business Research, Volume 8, Number 4.

Wernerfelt, B. (1984). A resource based view of the firm. Strategic Management Journal, Vol.5: 171-180. http://dx.doi.org/10.1002/smj.4250050207

Wright, Kroll, Pray and Lado. (1995). Strategic orientations, competitive advantage and business performance. Journal of Business Research, 33, 143-151. http://dx.doi.org/10.1016/0148-2963(94)00064-L

Wright, Patrick M., Gary C. McMahan, Blaine McCormick, and W. Scott Sherman1et. (1998). Strategy, Core Competence, and HR involvement as determinants of HR effectiveness and Refinery Performance. Human Resource Management, spring, Vol. 37, No. 1: 17-29.

Zhang X., and Bartol K.M. (2010). Linking Empowering leadership and employee creativity: The influence of Psychological Empowerment, Intrinsic Motivation and Creative engagement. Academy of Management Journal, Vol. 53, No. 1, 107-128. http://dx.doi.org/10.5465/AMJ.2010.48037118 
Table 1. Descriptive Statistics of core competence- Shared Vision

\begin{tabular}{|c|l|c|c|}
\hline No & \multicolumn{1}{|c|}{ Shared Vision } & Mean & SD \\
\hline 1 & The company mission is clear and coherent & 4.46 & 0.50 \\
\hline 2 & The company objectives are clear and coherent & 3.99 & 0.97 \\
\hline 3 & The company strategy is clear and coherent & 3.60 & 1.02 \\
\hline 4 & There is a strong feeling in the organizational that a common purpose exists & 3.91 & 0.81 \\
\hline 5 & I find that my values and the organizational values are very similar & 4.08 & 0.72 \\
\hline 6 & The strategic decision process is participative & 4.00 & 0.84 \\
\hline \multicolumn{2}{|r|}{ Shared Vision } & 4.01 & 0.81 \\
\hline
\end{tabular}

Table 2. Descriptive Statistics of core competence- Cooperation

\begin{tabular}{|c|l|c|c|}
\hline No & \multicolumn{1}{|c|}{ Cooperation } & Mean & SD \\
\hline 7 & All individuals are committed to the same project goals & 3.31 & 0.94 \\
\hline 8 & For most problems that arise, there are rules and procedures for dealing with them & 3.29 & 0.96 \\
\hline 9 & Individuals establish their own rules and procedures to facilitate the works progress & 3.83 & 0.76 \\
\hline 10 & There is a cooperative effort among individuals to carry out difficult tasks & 3.76 & 0.61 \\
\hline 11 & $\begin{array}{l}\text { There is an open communication among individuals, and the atmosphere is } \\
\text { characterized by friendly relations }\end{array}$ & 3.86 & 0.73 \\
\hline 12 & There is a high level of mutual trust & 3.67 & 0.89 \\
\hline 13 & Individuals actively work together as partners & 4.29 & 0.46 \\
\hline \multicolumn{2}{|c|}{ Cooperation } & 3.72 & 0.76 \\
\hline
\end{tabular}

Table 3. Descriptive Statistics of core competence -Empowerment

\begin{tabular}{|c|l|c|c|}
\hline No & \multicolumn{1}{|c|}{ Empowerment } & Mean & SD \\
\hline 14 & Decision Making tends to occur in a decentralized manner & 4.08 & 0.39 \\
\hline 15 & $\begin{array}{l}\text { Operating rules and standard procedures play important roles in how decisions are } \\
\text { handled }\end{array}$ & 4.05 & 0.37 \\
\hline 16 & Ideas tend to flow horizontally as vertically & 3.78 & 0.64 \\
\hline 17 & Decision Making responsibilities are pushed dawn to the lowest possible level & 3.88 & 0.48 \\
\hline 18 & Individuals are capable of directing and taking charge of their own work & 3.47 & 0.51 \\
\hline 19 & There are opportunities to select option and make choice at work & 3.45 & 0.50 \\
\hline 20 & The individual's knowledge base in this organization has increased & 4.05 & 0.37 \\
\hline 21 & Individuals have been given or taught the skills that are needed to arm themselves & 4.13 & 0.35 \\
\hline 22 & Individuals participate equally in organizational activities & 3.76 & 0.93 \\
\hline 23 & $\begin{array}{l}\text { There are opportunities for personal development such as growth in self-worth or } \\
\text { self-efficacy }\end{array}$ & 3.72 & 0.90 \\
\hline & & 3.84 & 0.54 \\
\hline
\end{tabular}


Table 4. Descriptive Statistics of Competitive Advantage- Flexibility

\begin{tabular}{|c|l|c|c|}
\hline No. & \multicolumn{1}{|c|}{ Flexibility } & Mean & SD \\
\hline 1 & $\begin{array}{l}\text { The company management assurance material and moral support to meet the needs and } \\
\text { aspirations of current and future clients }\end{array}$ & 3.81 & 0.83 \\
\hline 2 & $\begin{array}{l}\text { The company's management gives staff complete freedom to complete the work entrusted to } \\
\text { them }\end{array}$ & 4.02 & 0.81 \\
\hline 3 & $\begin{array}{l}\text { The company's management work on develop the employee performance and improve their } \\
\text { skills as required by the market of renewable }\end{array}$ & 3.65 & 0.85 \\
\hline 4 & $\begin{array}{l}\text { The company's management seeks to know the characteristics of the market for the } \\
\text { preparation of strategies and tactics appropriate for any situation possible current and future }\end{array}$ & 3.76 & 0.82 \\
\hline 5 & $\begin{array}{l}\text { The relationship between management and employee Features to efficiency and effectiveness } \\
\text { in order to complete customer orders }\end{array}$ & 3.64 & 0.91 \\
\hline \multicolumn{2}{|c|}{ General Arithmetic mean and standard deviation } & 3.78 & 0.84 \\
\hline
\end{tabular}

Table 5. Descriptive Statistics of Competitive Advantage- Responsiveness

\begin{tabular}{|c|c|c|c|}
\hline No. & Responsiveness & Mean & SD \\
\hline 6 & $\begin{array}{l}\text { Our operations system responds rapidly to changes in product volume demanded by } \\
\text { customers }\end{array}$ & 3.81 & 0.93 \\
\hline 7 & Our operations system effectively expedites emergency customer orders & 3.76 & 0.94 \\
\hline 8 & Our operations system rapidly reconfigures equipment to address demand changes & 3.89 & 0.91 \\
\hline 9 & Our operations system rapidly reallocates people to address demand changes & 4.17 & 0.79 \\
\hline 10 & Our operations system rapidly changes manufacturing processes to address demand changes & 3.41 & 1.08 \\
\hline 11 & Our operations system rapidly adjusts capacity to address demand changes & 3.74 & 0.95 \\
\hline \multicolumn{2}{|r|}{ Responsiveness } & 3.80 & 0.93 \\
\hline
\end{tabular}

Table 6. Descriptive Statistics of Organizational Performance- Growth

\begin{tabular}{|c|l|c|c|}
\hline No. & \multicolumn{1}{|c|}{ Growth } & Mean & SD \\
\hline 1 & The sales growth position relative to our principle competitor is & 3.87 & 0.92 \\
\hline 2 & My satisfaction with sales growth rate is & 3.91 & 0.91 \\
\hline 3 & The market share gains relative to our principle competitor are & 4.08 & 0.88 \\
\hline \multicolumn{2}{c|}{ Growth } & 3.95 & 0.90 \\
\hline
\end{tabular}

Table 7. Descriptive Statistics of Organizational Performance -Profitability

\begin{tabular}{|c|l|c|c|}
\hline No & \multicolumn{1}{|c|}{ Profitability } & Mean & SD \\
\hline 4 & The return on corporate investment position relative to our principle competition is & 3.92 & 0.85 \\
\hline 5 & My satisfaction with the return on corporate investment is & 4.00 & 0.79 \\
\hline 6 & My satisfaction with the return on Sales is & 4.01 & 0.77 \\
\hline 7 & The net profit position relative to our principle competitor is & 3.71 & 0.92 \\
\hline 8 & The financial liquidity position relative to our principle competitor is & 3.81 & 0.88 \\
\hline & Profitability & 3.89 & 0.84 \\
\hline
\end{tabular}


Table 8. Reliability analysis of core competence, competitive advantage and organizational performance

\begin{tabular}{|c|c|c|c|}
\hline \multirow{3}{*}{ Core Competence } & Number of items & Dimensions & Cronbach alpha \\
\cline { 2 - 4 } & 6 & Shared Vision & 85.5 \\
\cline { 2 - 4 } & 7 & Cooperation & 91.9 \\
\hline \multirow{2}{*}{\begin{tabular}{c} 
Competitive Advantage \\
\cline { 2 - 4 }
\end{tabular}} & 10 & Empowerment & 93.8 \\
\hline Organizational & 5 & Flexibility & 83.8 \\
\cline { 2 - 4 } Performance & 3 & Responsiveness & 89.4 \\
\hline \multicolumn{2}{|c|}{ Overall Questionnaire } & Profitability & 89.9 \\
\hline
\end{tabular}

Table 9. Summary of regression results - effect of Core Competence dimensions: Shared Vision; Cooperation and Empowerment on Organizational performance in Paint Industry in the UAE

\begin{tabular}{|c|c|c|c|c|c|c|}
\hline$(\mathrm{R})$ & $\left(\mathrm{R}^{2}\right)$ & $\mathrm{F}$ & \multicolumn{2}{|c|}{$\beta$} & d. f. & Sig* \\
\hline \multirow{3}{*}{0.861} & \multirow{3}{*}{0.741} & \multirow{3}{*}{33.820} & Shared Vision & 0.605 & 3 & \\
\cline { 4 - 6 } & & & Cooperation & 0.190 & 60 & \multirow{2}{*}{0.000} \\
\cline { 4 - 6 } & & Empowerment & 0.242 & 63 & \\
\hline
\end{tabular}

Dependent variable: Organizational performance, the impact is significant at level $(\alpha \leq 0.05)$

Table 10. Summary of regression results - effect of core competence dimensions: Shared Vision; Cooperation and Empowerment on Competitive Advantage in Paint Industry in the UAE

\begin{tabular}{|c|c|c|c|c|c|c|}
\hline$(\mathrm{R})$ & $\left(\mathrm{R}^{2}\right)$ & $\mathrm{F}$ & \multicolumn{2}{|c|}{$\beta$} & d.f. & Sig* \\
\hline \multirow{3}{*}{0.600} & \multirow{3}{*}{0.360} & \multirow{3}{*}{11.257} & Shared Vision & 0.584 & 3 & \\
\cline { 4 - 6 } & & & Cooperation & 0.112 & 60 & \multirow{2}{*}{$\mathbf{0 . 0 0 0}$} \\
\cline { 4 - 6 } & & Empowerment & 0.115 & 63 & \\
\hline
\end{tabular}

* Dependent variable: Competitive Advantage, the impact is significant at level $(\alpha \leq 0.05)$

Table 11. Summary of regression results - effect of competitive advantage dimensions: flexibility and Responsiveness on Organizational performance in Paint Industry in the UAE

\begin{tabular}{|c|c|c|c|c|c|c|}
\hline$(\mathrm{R})$ & $\left(\mathrm{R}^{2}\right)$ & \multicolumn{2}{|c|}{$\beta$} & $\mathrm{F}$ & $\mathrm{D} \mathrm{f}$ & \multirow{2}{*}{ Sig* } \\
\hline \multirow{3}{*}{0.552} & \multirow{3}{*}{0.305} & Flexibility & 0.453 & \multirow{2}{*}{13.361} & 2 & \\
& & & & \multirow{2}{*}{$\mathbf{0 . 0 0 0}$} \\
& & Responsiveness & 0.138 & & 63 & \\
\hline
\end{tabular}

*Dependent variable: Organizational performanceg the impact is significant at level $(\alpha \leq 0.05)$.

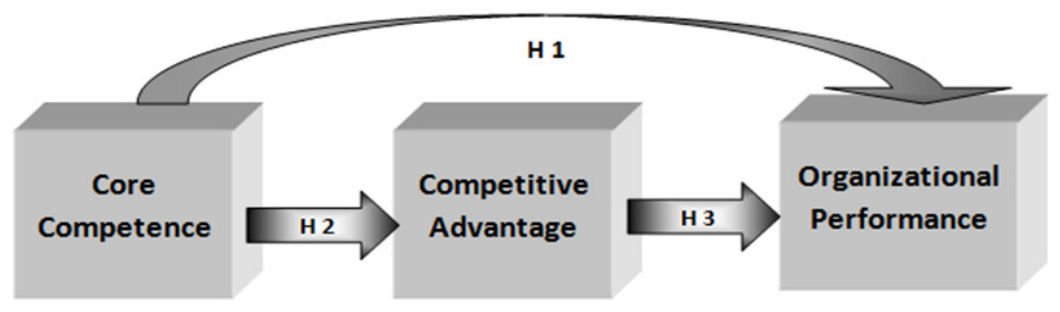

Figure 1. The conceptual model 